\title{
Effectiveness of mycorrhizal fungi in the protection of juniper, rose, yew and highbush blueberry against Alternaria alternata
}

\author{
Stanisław Mazur ${ }^{1 *}$, Malgorzata Nadziakiewicz' ${ }^{2}$, \\ Halina Kurzawińska ${ }^{1}$,Jacek Nawrocki ${ }^{I}$ \\ ${ }^{1}$ Department of Plant Protection \\ Faculty of Biotechnology and Horticulture, University of Agriculture in Krakow \\ 29 Listopada 54, 31-425 Kraków, Poland \\ ${ }^{2}$ Ciech Sarzyna S.A. \\ Chemików 1, 37-310 Nowa Sarzyna, Poland
}

\begin{abstract}
After conducting two-year observations in nurseries in the Małopolska province, Poland, the species of shrubs on which symptoms of discoloration and withering of the leaves/needles and shoots, and sometimes of whole plants, occurred most frequently were selected for further study. The species included juniper (Juniperus horizontalis 'Wiltonii', rose (Rosa 'Star Profusion'), yew (Taxus $\times$ media 'Hillii') and highbush blueberry (Vaccinum corymbosum 'Patriot'). The predominant fungus isolated from the diseased plants was Alternaria alternata (Fr.) Keissl. A pathogenicity test performed in the laboratory confirmed the pathogenic effects of A. alternata on all of the tested species of shrubs. In 2011-2014, a field experiment was conducted with $A$. alternata inoculum introduced into the growth substrate. The presence of the pathogen reduced considerably the annual growth of all the shrubs tested. The applied mycorrhizal inocula had an effect on some morphological characteristics of plants, such as height and number of shoots. Moreover, the plants whose roots had been treated with the mycorrhizal inocula and were grown in the substrate inoculated with the pathogen also achieved greater increases in growth in comparison with the plants treated with the pathogen as well as relative to the control. The protective role of mycorrhizal inocula against the damaging effects of the pathogen was evident in all the species of shrubs.
\end{abstract}

Key words: Alternaria, ectomycorrhizal inocula, pathogen, disease management

\section{INTRODUCTION}

One of the effects of economic development, increasing industrialization and urbanization has been the growing significance of ornamental plants in human life. Of importance are not only the ornamental and aesthetic values of plants, but also their influence on human health and well-being by providing peace and safety, reducing tension and stresses, increasing concentration, and also improving interpersonal relations. In 2002, Poland became the fifth producer in Europe of ornamental plants (Jabłońska et al., 2014). Research on diseases of nursery plants in Poland is rarely conducted and not sufficient to provide a comprehensive source of information needed for effective elimination from

*Corresponding author. 
nurseries. For several years, nursery producers have been reporting disease symptoms appearing on the aboveground parts of some species of shrubs. Initially, it was a change in colour of shoot/ needle tips and development of lesions on the leaves of deciduous plants, followed by withering of the affected parts. Even if the death of the whole plant was not observed, the injuries were extensive enough to make the plant unsuitable as a commercial material.

The nature of plant production is such that it is impossible to separate it from the influence of external factors. In recent years, the problem of fungal diseases on ornamental plants has been growing in importance due to the increasing frequency of their occurrence and the extent of injuries increasing from year to year. Numerous fungal pathogens cause leaf spots and defoliation of nursery plants, but arguably the most prevalent and troublesome are those caused by Alternaria species. Leaf spots caused by Alternaria rarely kill plants, but they can reduce their aesthetic quality and commercial value (Mamgain et al., 2013). Alternaria infections can cause leaf spots or blotches, blighting and blackening of young shoots as well as stem and radicle lesions. Affected leaves develop brown to black spots or blotches which can vary considerably in size, colour and shape. These leaves may fall prematurely. Some Alternaria species, particularly pathovars of A. alternata, depend on toxin production for colonization of their host. Some of these produce a toxin which translocates through the vascular system producing chlorosis along the veins from the leaf lesion, and causing death of adjacent leaf tissue. Others produce a toxin with a mild phytotoxic effect such as a yellow halo surrounding a necrotic spot (Pegg et al., 2014).

Infection of the leaves usually leads to the development of chlorotic and necrotic areas, resulting in a decrease in the production of photosynthetic assimilates (Ciuffetti et al., 2010). This reduction in photosynthesis can be attributed to the destructive action of a pathogen (Chen et al., 2005).

Some pathogens infect many species of shrubs, and their occurrence is becoming more common. Fungi of the genus Alternaria, due to their prevalence and genetic variation, constitute a major threat in the cultivation of plants (Kakvan et al., 2012). One such species is Alternaria alternata (Fr.) Keissl., which can be found in the tissues of various plants and in the soil around the world. It can cause injuries to many plant species in different ecosystems (Bagherabadi et al., 2015). Goetz and Dugan (2006) have pointed out the presence of Alternaria spp. in the rhizosphere of coniferous plants and their pathogenicity towards such plants. As early as 1960, Pomerleau and Nadeau named the fungi of Alternaria spp. as the cause of withering of $20-65 \%$ of conifer seedlings in nurseries. Similarly, James and Woo (1987) found that seedlings of coniferous plants infected by Alternaria alternata withered away completely.

The genus Alternaria is characterized by the formation of polymorphic conidia. Spores of these polyphagous fungi are widely distributed in the atmosphere and soil. Their elongated shape allows them to be easily spread by the wind, which increases their distribution (Mamgain et al., 2013).

Infections caused by fungi of the genus Alternaria also affect nursery plants. Rodino et al. (2014) reported the presence of A. alternata not only on many agricultural and horticultural crops, but also on some weeds and ornamentals. Sharma et al. (2013) found that analyses performed on genomic DNA from A. alternata isolates obtained from various host plants showed a high level of genetic variation conducive to the colonization of different plant species.

Knowledge of the soil environment plays a major role in providing information on its beneficial characteristics that ensure a satisfactory state of plant health (Kurzawińska, 2006). One of the methods of protecting plants against phytopathogens is the use of antagonistic microorganisms to control the populations of pathogenic microbes. Some fungi commonly occurring in nature exhibit antagonistic action against the fungi that cause diseases in plants, while not endangering the root system. They can also stimulate growth and induce resistance in plants (Świerczyńska et al., 2011). There are wellknown examples of the use of mycorrhizal fungi to protect various plants against infection by a broad spectrum of pathogens (Prasad and Rangeshwaran, 2000; Kredics et al., 2001).

One method that helps to obtain healthy nursery material is the use of mycorrhizal inocula. Mycorrhiza means "fungus root" and describes a mutually beneficial, symbiotic relationship between fungi and plant roots (Buechel and Bloodnick, 2016). Mycorrhizal symbiosis is the oldest common form of symbiosis between fungi and plants (Finlay, 2008). Of importance here is the protection of the root system against infection by pathogenic microorganisms. By inhabiting the 
interior of roots, the hyphae of mycorrhizal fungi form a mechanical barrier to pathogens, induce defence mechanisms of the plant's root system, and reduce the activity of harmful microbes in the rhizosphere. The protection is provided by a mantle of mycorrhizal fungi around the short roots. These structures can also increase the resistance of plants biochemically by stimulating the synthesis of chemical substances such as phenolic compounds or phytoalexins responsible for the development of plant resistance to disease (Vayssières et al., 2015)

Mycorrhizal fungi not only enhance plant growth and health, but also promote the formation of a better structure of the growth substrate and the biological life in the root zone. Mycorrhizal fungi perform many useful functions for plants, such as increasing the area of the absorptive surface and thereby providing the roots with a better supply of water and essential minerals, including microelements. They also improve growth conditions under unfavourable soil $\mathrm{pH}$, soil salinity, and elevated temperatures. The good health of plants means an additional protection against pathogenic fungi, whose inactivity is also controlled by mycorrhizal fungi (Smith and Read, 2008; Schirkonyer et al., 2013).

Fungi are key organisms in the functioning of ecosystems, and while we may marvel at their great numbers, understanding their functional diversity is critical to comprehending their importance in ecosystem health (Molina, 1994).

Nursery producers still relatively seldom take advantage of mycorrhizal fungi, underestimating their prophylactic role in helping to obtain healthy plants. The aim of the experiment was to determine the effect of mycorrhizal inocula on the growth, development and health of selected species of shrubs in nurseries and also in substrate infected with an inoculum of $A$. alternata.

\section{MATERIAL AND METHODS}

Based on surveys and observations of nurseries in the Małopolska province, Poland, conducted in 2010-2011, five plants of each of the species Juniperus horizontalis 'Wiltonii', Rosa 'Star Profusion', Taxus $\times$ media 'Hillii' and Vaccinum corymbosum 'Patriot' the most visible symptoms of disease were chosen for testing. In 2011, 3-year-old plants with disease symptoms such as discoloration, necrotic lesions, withering of the leaf blade/needles and shoots, were taken from selected 5 nurseries. From each plant, 6 leaves or needles, depending on the plant, were taken. In the laboratory, all of the samples were initially rinsed with water. Then, using a sterile scalpel, fragments were taken from the borderline between necrotic lesions and healthy tissue; these were cut into $0.5-1.0 \mathrm{~cm}$ pieces and subjected to surface disinfection (in the sequence: sterile distilled water, $75 \%$ solution of ethyl alcohol, sterile distilled water). The disinfected plant material was thoroughly dried with sterile absorbent paper and laid out, 4 pieces at a time, on a glucosepotato medium and a pea medium in Petri dishes. Successively appearing colonies of fungi were split off and inoculated onto PDA slants after a period of incubation in a thermostat at a temperature of 22$23^{\circ} \mathrm{C}$ for 4-7 days. After homosporous cultures had been obtained, they were transferred onto suitably selected media and identified to the level of species. In addition to the PDA medium, rice and potato media were also used to identify fungi of the genus Fusarium. The isolated fungi were identified using mycological keys (Ellis and Ellis, 1988; Dugan, 2006; Domsch et al., 2007; Klaus et al., 2008). The frequency of occurrence of the different species of fungi was determined on the basis of the number of the obtained isolates of a given fungal species, which was expressed as a percentage. On this basis, fungi recognized as potentially pathogenic were selected for a field experiment.

The field experiment was conducted in Krosno, Poland, in 2011-2014. It was established towards the end of June 2011. The Target universal substrate with the parameters: organic matter content $-58.7 \%, \mathrm{pH}$ 4.7 (in $\mathrm{H}_{2} \mathrm{O}$ ), electrical conductivity $(\mathrm{EC})-1.3 \mathrm{mS}$ $\mathrm{cm}^{-1}$, field water capacity (FWC) $-17.6 \%$ by weight, moisture content $-12.3 \%$ by weight was used.

The plants used in the experiment were 1-yearold well-rooted plants in P-9 containers: Juniperus horizontalis 'Wiltonii', Rosa 'Star Profusion', Taxus $\times$ media 'Hillii'. Plants of Vaccinum corymbosum 'Patriot' had been derived by propagation in vitro, and were a dozen or so centimeters tall. The tested species of shrubs were planted in 5 litre pots and placed in groups of five in furrows prepared in advance and lined with a nursery fabric. The experiment included the following combinations:

1. control - shrubs growing in a substrate without any treatments,

2. shrubs growing in a substrate inoculated with Alternaria alternata,

3. shrubs with the root system inoculated with mycorrhizal fungi,

4. shrubs with the root system inoculated with mycorrhizal fungi and growing in a substrate inoculated with A. alternata. 
The experiment was established in three replicates, and each replicate consisted of 5 plants. The field experiment included the use of $A$. alternata isolates obtained from the shrubs from the nursery characterized by the highest number of plants with disease symptoms in 2011. Species of the above mentioned shrubs in the field experiment were inoculated with isolates obtained from the same species. A substrate was prepared in the laboratory, and consisted of Target universal substrate, sand and wheat bran in a 1:1:1 ratio. The substrate was used to fill 1 litre flasks, which were secured with aluminum foil and paper, and then autoclaved twice. 14-day-old cultures of A. alternata isolated from the test shrubs were ground in a mortar with sterile sand and introduced into the substrate (one Petri dish per flask). After three weeks of incubation at $20-25^{\circ} \mathrm{C}$, the substrate in the flasks was overgrown with the mycelium. For each plant species, 6 flasks were prepared. The substrate overgrown with the fungus was added to the growth substrate intended for the respective combinations in the field experiment, in an amount of 1 litre per 50 litres of substrate.

The mycorrhizal inocula used in the field experiment as a water-gel suspension were produced by Mykoflor (Mykoflor - Laboratory of Mycorrhizal Fungi, Rudy 84, 24-130 Końskowola, Poland). The composition of the ectomycorrhizal fungi, according to the manufacturer's specifications, was as follows:

- inoculum for coniferous plants: Suillus luteus, $S$. grevillei, Amanita muscaria, Amanita gemmata, Scleroderma areolatum and root isolates, used for Juniperus spp., and Taxus spp.,

- inoculum for highbush blueberry: Hymenoscyphus spp. and root isolates, used for Vaccinum spp.,

- inoculum for roses: specific root isolates of wild roses, used for Rosa spp.

Before planting, a suspension of the mycorrhizal inoculum was prepared: 100 grams of hydrogel (HydroŻel, Chem-Jan) and $250 \mathrm{ml}$ of the mycorrhizal inoculum suitable for a given plant species were added to $2 \mathrm{~L}$ of water. The root system of plants (for the combinations with mycorrhizal fungi) was immersed for 2 minutes in the resulting solution before planting them into pots with the growth substrate. Throughout the period of the field experiment, the plants were not fertilized and no chemical protection was applied. They were watered with water from a well, with a frequency corresponding to the weather conditions. During the field experiment, observations of plant health were carried out every 2 weeks and all disease symptoms such as discoloration, necrotic lesions, withering of the leaf blade/needles and shoots were recorded.

All of the plants in the field experiment had their height measured immediately after planting. The second measurement was made in October 2011, i.e. in the first year of the experiment. Subsequent measurements were performed every year in October, in 2012, 2013 and 2014. The obtained results were statistically analyzed (computer program Statistica 12) using two-way ANOVA. The significance of the differences in plant growth between the combinations was tested using Tukey's test at a significance level of $p=0.05$.

\section{RESULTS AND DISCUSSION}

Symptoms of discoloration and withering of the leaves/needles and shoots, and sometimes of whole plants, occurred on all of the examined shrubs in all of the nurseries selected for the study. In both years of observations of the health of shrubs of the selected species, the percentage of infected plants was high, reaching values of more than $46.0 \%$ in all of the nurseries. According to Atilano (1983), the lesions on the leaves caused by Alternaria spp. are endemic to many species of plants grown in nurseries.

On the basis of the results obtained in the isolation of fungi colonizing the aboveground parts, the base of the shoots, and the roots of the test shrubs, it was found that the most numerous of all the isolates obtained was $A$. alternata. The percentage share of this pathogen among the isolates obtained from all the parts of plants combined was very high for juniper, rose and yew shrubs and ranged from $42.0 \%$ to $47.5 \%$ of the total number of isolates (Fig. 1-4). This is consistent with the information in the literature (Abeer et al., 2014), indicating the prevalence of fungi of the genus Alternaria. Some of them, known to be pathogenic, are destructive to plants (Mamgain et al., 2013).

Many authors (Kurzawińska and Duda-Surman, 2008; Ghosh et al., 2009; Nasim et al., 2012; Pegg et al., 2014) have indicated that Alternaria spp. can infect the leaves, stems, flowers, fruits, and the roots of ornamental plants. A. alternata occurs worldwide (Woudenberg et al., 2014) in various environmental conditions (Grunden et al. 2001). Pusz (2009) has suggested the ability of $A$. alternata to easily adapt to closely related host plants. 

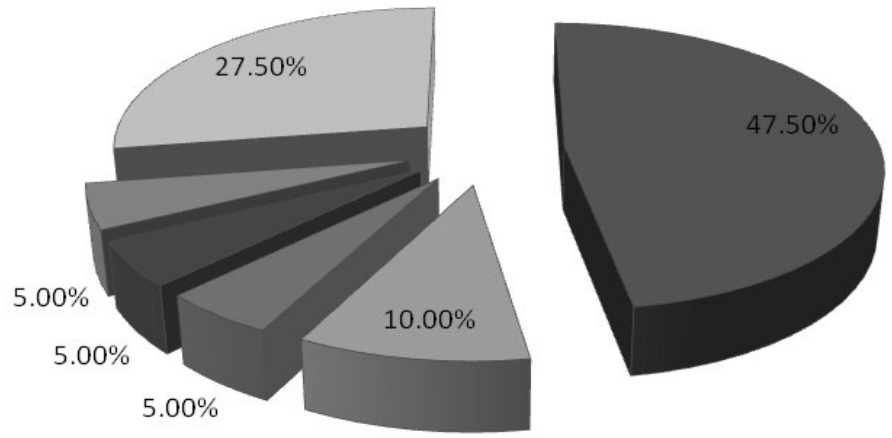

Alternaria alternata $47.50 \%$

口 Botrytis cinerea $10.00 \%$

口Fusarium oxysporum $5.00 \%$

- Trichoderma koningi $5.00 \%$

口Fusarium avenaceum $5.00 \%$

口Other $27.50 \%$

Figure 1. The percentage of fungal colonies isolated from diseased juniper shrubs

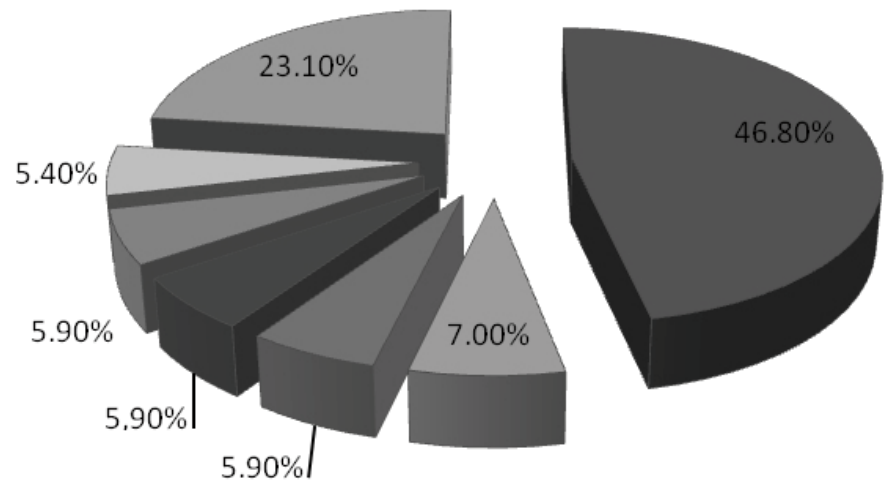

Alternaria alternata $46.80 \%$

$\square$ Sclerotinia sclerotiorum $7.00 \%$

$\square$ Penicillium spp. $5.90 \%$

Botrytis cinerea $5.90 \%$

口Trichoderma polysporum $5.90 \%$

$\square$ Fusarium avenaceum $5.40 \%$

口Other $23.10 \%$

Figure 2. The percentage of fungal colonies isolated from diseased rose shrubs
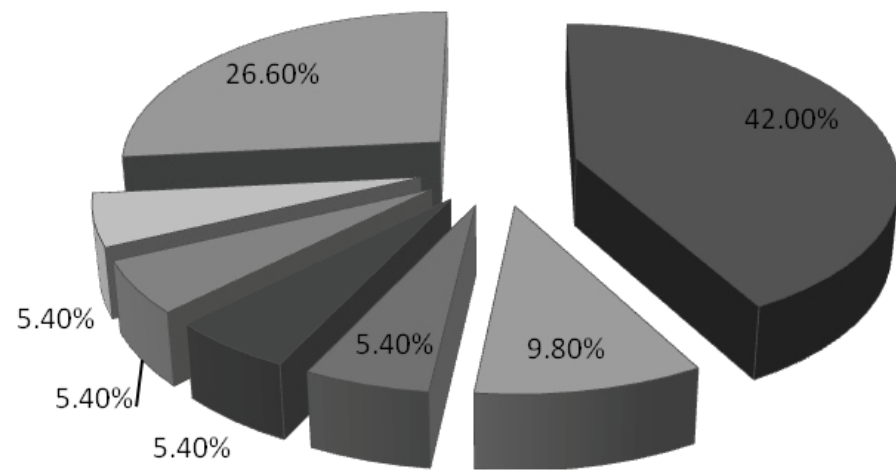

Alternaria alternata $\mathbf{4 2 . 0 0 \%}$

口 Botrytis cinerea $9.80 \%$

口Fusarium culmorum $5.40 \%$

Pestalotia sydowiana $5.40 \%$

$\square$ Rhizoctonia solani $5.40 \%$

口Fusarium oxysporum $5.40 \%$

口Other $26.60 \%$

Figure 3. The percentage of fungal colonies isolated from diseased yew shrubs
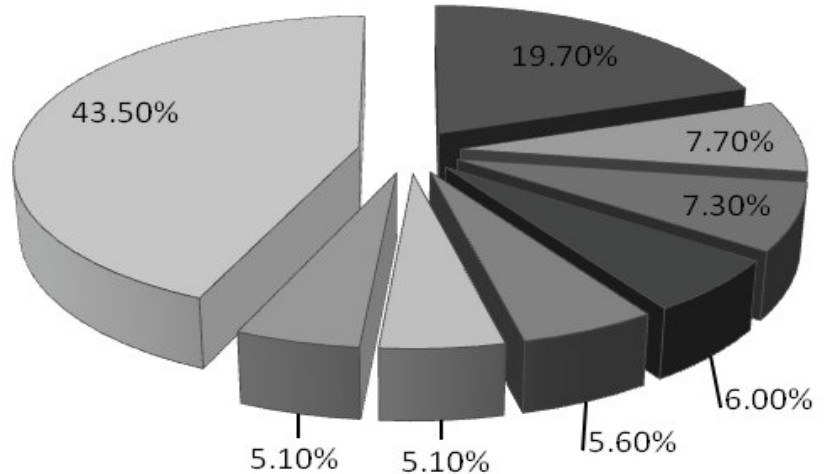

Alternaria alternata $19.70 \%$

口Trichoderma koningi $7.70 \%$

口 Fusarium oxysporum $7.30 \%$

- Sclerotinia sclerotiorum $6.00 \%$

口Diaporthe vaccini $5.60 \%$

$\square$ Exobasidium vaccini $5.10 \%$

口Fusarium culmorum $5.10 \%$

$\square$ Other $43.50 \%$

Figure 4. The percentage of fungal colonies isolated from diseased highbush blueberry plants 
The presence of A. alternata in the substrate strongly influenced the growth of juniper shrubs. The plants produced very little new growth, and the colour of the needles on some of the shoots had a light celadon tinge. There was less new growth on juniper shrubs in the second year of the experiment than in the first in all the combinations. In the third year, a lot of new growth was observed on the plants treated with the mycorrhizal inoculum. The growth in this combination was several times greater than in the control (Tab. 1).

Taking into account the average growth over the years 2011-2014, it was found that there were very marked differences in the growth of juniper shrubs (Tab. 5). The plants from the control combination were characterized by relatively poor growth, probably resulting from the lack of supplementary feeding. They were green and showed no symptoms of disease. The juniper shrubs growing in the substrates which Alternaria alternata had changes in colour of the tips of shoots. Initially, they were celadon green, and later withered away. The needles closer to the base of the shoots were dying. The growth of those shrubs was inhibited. The growth of juniper shrubs with mycorrhizal inoculum was $136.7 \%$ greater than in the control (Tab. 5); moreover, those plants showed no symptoms of disease. It was found that the application of mycorrhizal inoculums had a significant effect on the growth of shrubs. Shrubs growing in the substrate inoculated with both $A$. alternata and mycorrhizal inoculum exhibited no symptoms of disease. The shrubs treated with mycorrhizal fungi were more bushy than in the other combinations. The literature contains very few reports on the diseases caused by $A$. alternata in junipers. Blake et al. (2006) reported on the occurrence of infection of juniper needles caused by A. alternata (Alternaria needle blight).

The rose shrubs also responded clearly to the presence of A. alternata. Already in the second year, the field experiment showed evident differences between the combinations. The rose shrubs grown in the substrate inoculated with $A$. alternata had many discoloured and crumbling stems. The decorative effect had been completely lost. The annual growth of roses was smaller in the second year of the experiment compared with the first year in all the combinations, except for the bushes treated with the mycorrhizal inoculum. In the third year, a very large increase in the annual growth of plants was observed in this combination. It was almost 6 -fold higher compared with that of the control plants. In the third year of the experiment, the average annual growth of roses in the substrate inoculated with A. alternata was the lowest (Tab. 2).

Taking into account the average growth of rose shrubs over the years 2011-2014, it was found that

Table 1. Average annual growth in juniper in 2011-2014

\begin{tabular}{lccc}
\hline & \multicolumn{3}{c}{ Average annual growth $(\mathrm{cm})$} \\
\cline { 2 - 4 } Combination & Oct 2011 & Oct 2012 & Oct 2013 \\
\hline Control - shrubs growing in substrate without any treatment & 15.9 & 4.8 & 3.3 \\
Shrubs growing in substrate inoculated with Alternaria alternata & 12.1 & 4.8 & 3.7 \\
Shrubs with root system treated with mycorrhizal inoculum & 20.3 & 12.4 & 29.6 \\
Shrubs with root system treated with mycorrhizal inoculum and & \multirow{2}{*}{-Oct 2012} & 6.1 \\
growing in substrate inoculated with A. alternata & & 7.2 & 6.3 \\
\hline
\end{tabular}

Values in columns marked with the same letters do not differ statistically significantly at the significance level $p=0.05$ according to Tukey's test

Table 2. Average annual growth in rose in 2011-2014

\begin{tabular}{lccc}
\hline & \multicolumn{3}{c}{ Average annual growth (cm) } \\
\cline { 2 - 3 } Combination & Oct 2011 & Oct 2012 & Oct 2013 \\
& -Oct 2012 & -Oct 2013 & 7.3 \\
\hline Control - shrubs growing in substrate without any treatment & 22.7 & 7.7 & 0.1 \\
Shrubs growing in substrate inoculated with Alternaria alternata & 14.8 & 2.7 & 42.1 \\
Shrubs with root system treated with mycorrhizal inoculum & 23.2 & 24.4 & 17.5 \\
Shrubs with root system treated with mycorrhizal inoculum and & 22.5 & 11.9 & \\
growing in substrate inoculated with A. alternata & &
\end{tabular}

Values in columns marked with the same letters do not differ statistically significantly at the significance level $p=0.05$ according to Tukey's test 
the plants in the combinations without the prior introduction of the A. alternata inoculum into the substrate were green and showed no symptoms of disease. The roses grown in the substrate inoculated with A. alternata changed the colour of the tips of shoots first to burgundy and then to grey, after which they died and crumbled away. The growth of the rose shrubs planted in the substrate inoculated with A. alternata was inhibited. The growth of the rose shrubs from the combination with the root system treated with the mycorrhizal inoculum was more than twice as high as that of the control shrubs. The plants in this combination showed no symptoms of disease. Smaller growth was shown by the roses from the substrate inoculated with A. alternata and root system treated with the mycorrhizal inoculum. However, it was larger than the growth of the control plants (Tab. 5). Those plants exhibited no symptoms of disease. The plants in all the combinations with mycorrhizal fungi had more shoots compared to the other combinations. Based on these results, it can be concluded that A. alternata is pathogenic towards rose and can result in significant changes in plant growth, development and health, and even lead to the death of plants. The effect of A. alternata on rose shrubs can cause the loss of their ornamental value. Already in 1982, Chase was reporting that Alternaria spp. caused diseases of ornamental plants, including roses. In the cultivation of roses, of particular importance are the decorative qualities, not only of the flowers, but also of the leaves, and therefore the health of the shrubs. In India, spots on the leaves of roses have been described as caused by Alternaria spp. The injuries caused by this fungus on the cultivated species of roses have been recognized as having great economic importance (Abbas et al., 2017).

In all the years of the experiment, the yew shrubs grown in the substrate inoculated with A. alternata grew very poorly. The highest increases in growth were achieved by the yew shrubs whose root system had been inoculated with the mycorrhizal inoculum (Tab. 3). Comparing the shrubs growing in the substrate with the pathogen, it was found that the yew shrubs with the root system treated with the mycorrhizal inoculum had achieved, in all the years, higher annual growth than the shrubs from the control combination and the shrubs with the pathogen inoculum introduced into the substrate but without the mycorrhizal inoculum. The greatest difference was in the third year of the experiment. By contrast, little difference was found between the shrubs with the root system treated with the mycorrhizal inoculum and growing either in the substrate inoculated with the pathogen or the substrate without $A$. alternata (Tab. 3).

Taking into account the average growth of yew shrubs over the period 2011-2014, it was found that the shrubs whose root system had been treated with the mycorrhizal inoculum and growing either in the substrate with the A. alternata inoculum or in the substrate without it had achieved similar growth, much higher in comparison with the growth of plants in the control combination (Tab. 5). It was found that the shrubs in the combinations with the root system treated with the mycorrhizal inoculum had more shoots in comparison with the other combinations, and showed no symptoms of disease. The yew shrubs growing in the substrates inoculated with A. alternata had changed the colour of the needles at the tips of the shoots, similar to the nursery plants. They were initially celadon green, but later changed to light brown and withered away. Inhibition of growth also suggests that $A$. alternata can be a pathogen able to cause significant losses in the cultivation of yew shrubs in nurseries. Mirski (2008) found that A. alternata was the dominant species among the isolates of the living and dead parts of yew plants.

The shoots of the highbush blueberry shrubs growing in the substrate inoculated with A. alternata

Table 3. Average annual growth in yew in 2011-2014

\begin{tabular}{|c|c|c|c|}
\hline \multirow[b]{2}{*}{ Combination } & \multicolumn{3}{|c|}{ Average annual growth $(\mathrm{cm})$} \\
\hline & $\begin{array}{l}\text { Oct } 2011 \\
- \text { Oct } 2012\end{array}$ & $\begin{array}{r}\text { Oct } 2012 \\
- \text { Oct } 2013\end{array}$ & $\begin{array}{l}\text { Oct } 2013 \\
\text {-Oct } 2014\end{array}$ \\
\hline Control - shrubs growing in substrate without any treatment & 15.9 & 9.9 & 13.3 \\
\hline Shrubs growing in substrate inoculated with Alternaria alternata & 1.7 & 2.0 & 1.2 \\
\hline Shrubs with root system treated with mycorrhizal inoculum & 16.5 & 11.6 & 41.1 \\
\hline $\begin{array}{l}\text { Shrubs with root system treated with mycorrhizal inoculum and } \\
\text { growing in substrate inoculated with } A \text {. alternata }\end{array}$ & 15.7 & 11.4 & 43.3 \\
\hline
\end{tabular}

Values in columns marked with the same letters do not differ statistically significantly at the significance level $p=0.05$ according to Tukey's test 
Table 4. Average annual growth in highbush blueberry in 2011-2014

\begin{tabular}{lccc}
\hline & \multicolumn{3}{c}{ Average annual growth $(\mathrm{cm})$} \\
\cline { 2 - 3 } Combination & Oct 2011 & Oct 2012 & Oct 2013 \\
& -Oct 2012 & -Oct 2013 & -Oct 2014 \\
\hline Control - shrubs growing in substrate without any treatment & 26.4 & 9.3 & 15.2 \\
Shrubs growing in substrate inoculated with Alternaria alternata & 17.9 & 3.1 & 1.5 \\
Shrubs with root system treated with mycorrhizal inoculum & 30.9 & 14.5 & 19.6 \\
Shrubs with root system treated with mycorrhizal inoculum and & 13.7 & 14.5 & 13.2 \\
growing in substrate inoculated with A. alternata & &
\end{tabular}

Values in columns marked with the same letters do not differ statistically significantly at the significance level $p=0.05$ according to Tukey's test

were found to have discoloured to a burgundybrown colour. Moreover, the number of damaged shoots increased from year to year. The differences in annual growth were already seen in the second year. The annual growth of the shrubs growing in the substrate inoculated with $A$. alternata was the smallest in the third year (Tab. 4).

Taking into account the average growth of blueberry shrubs over the years 2011-2014, it was found that there were marked differences in the growth of those shrubs (Tab. 5). The leaves of blueberry shrubs in all the combinations throughout the growing season were green and showed no visible symptoms of disease. The blueberry shrubs growing in the substrates inoculated with A. alternata were found to have changed the colour of the tips of their shoots. Initially, they were burgundy-brown, then changed the colour to greybrown, withered and crumbled away at the tips. The growth of those shrubs was inhibited. The growth of blueberry shrubs from the combinations in which the root system had been treated with the mycorrhizal inoculum was $24.8 \%$ greater than in the control (Tab. 5). Those shrubs showed no symptoms of disease and were more bushy. Also in the substrates inoculated with A. alternata, the shrubs with roots treated with mycorrhizal inoculum grew better. Analysis of the health status and annual growth of blueberry bushes in the field experiment showed that the fungus A. alternata could be pathogenic for this plant species.

The differences in the average growth of the tested shrubs over the entire period of the field experiment were statistically significant for all the species (Tukey's test at the significance level $p=$ 0.05). Comparing the average growth of the shrubs over the years 2011-2014, the largest significant differences were found between the shrubs whose root system had been treated with the mycorrhizal inoculum, on the one hand, and the growth of the shrubs growing in the substrates inoculated with A. alternata and those in the control, on the other hand (Tab. 5). Calculations of two-factor ANOVA for all the species of shrubs indicate a significant effect of the experimental combination on their growth. It was also found that the presence of A. alternata in the substrate negatively affected the growth, development and health of the tested shrubs. Guo et al. (2004) have also reported that this species of fungus is an obligate pathogen that infects many different crop plants.

The problem of fungal diseases on ornamental plants has become increasingly important in recent years due to the growing frequency of their occurrence and the growing extent of injuries they cause from year to year. The importance of the fungus A. alternata as a pathogen in Poland is all the greater because it finds here favourable climatic conditions for its development (Mazur et al., 2015).

Table 5. Total growth of shrubs in field experiment (average for the period 2011-2014)

\begin{tabular}{|c|c|c|c|c|}
\hline Combination & Juniper & Rose & Yew & $\begin{array}{l}\text { Highbush } \\
\text { blueberry }\end{array}$ \\
\hline Control - shrubs growing in substrate without any treatment & $29.4 \mathrm{~b}$ & $41.1 \mathrm{~b}$ & $42.9 \mathrm{~b}$ & $57.3 \mathrm{c}$ \\
\hline Shrubs growing in substrate inoculated with Alternaria alternata & $24.8 \mathrm{a}$ & $19.8 \mathrm{a}$ & $9.2 \mathrm{c}$ & $29.5 \mathrm{a}$ \\
\hline Shrubs with root system treated with mycorrhizal inoculum & $69.6 \mathrm{~d}$ & $91.7 \mathrm{~d}$ & $74.2 \mathrm{a}$ & $71.5 \mathrm{~d}$ \\
\hline $\begin{array}{l}\text { Shrubs with root system treated with mycorrhizal inoculum and } \\
\text { growing in substrate inoculated with } A \text {. alternata }\end{array}$ & $34.8 \mathrm{c}$ & $54.5 \mathrm{c}$ & $75.2 \mathrm{a}$ & $48.1 \mathrm{~b}$ \\
\hline
\end{tabular}

Values in columns marked with the same letters do not differ statistically significantly at the significance level $p=0.05$ according to Tukey's test 
Based on the results of the field experiment, the mycorrhizal inocula were found to have a positive effect on the growth, development and health of shrubs. This effect was significant for all of the tested species of shrubs. In the combination with mycorrhizal fungi, all of the tested shrubs grew faster and were more bushy compared with shrubs from the other combinations. Among the tested species of shrubs, the most pronounced effect of the applied mycorrhizal inoculum was in rose. The presence of mycorrhizal fungi in the substrate considerably improved the condition of the shrubs and stimulated stronger growth. There was also a beneficial effect of mycorrhizal fungi in the presence of the pathogen in the growth substrate. The effect obtained by the introduction of mycorrhizal fungi into the substrate confirmed its positive role in the protection of plants against diseases. There is considerable published research in the world literature proving the biological, physiological and ecological significance of ectomycorrhizae and vesicular-arbuscular mycorrhizae (VAM) to the survival, growth, development and health of many species of agricultural and horticultural plants, and of forest trees (Marx et al., 2002). This role of mycorrhizal fungi allows them to be used for the protection of plants against diseases. During the field experiment, the mycorrhizal inocula were observed to have only a weak effect in the first years after planting. The effect of mycorrhizal inocula was most evident in the third year of vegetative growth. According to Aleksandrowicz-Trzcińska (2008), it can happen, especially in the first years of the life of plants, that abundant mycorrhizas inhibit plant growth, which is caused by the need to redirect even up to $30 \%$ of the products of photosynthesis by the host plant to the fungal partner. This phenomenon should be seen as a natural physiological process. After 2-3 years, the well-mycorrhized plants usually compensate for the time of slower growth, and even surpass those without mycorrhizal fungi.

Although the plants were not fed throughout the period of the experiment, thanks to the useful role of mycorrhizal fungi in the uptake of nutrients, the shrubs with the root system treated with a mycorrhizal inoculum were notable for greater growth and better healthiness and development. Marx etal.(2002) proved the biological,physiological and ecological significance of ectomycorrhizae and vesicular-arbuscular mycorrhizae (VAM) to the survival, growth, development and health of many species of agricultural and horticultural plants and of forest tree species.
In the experiment it was found that the fungus A. alternata is pathogenic for the tested species of shrubs and can cause significant economic losses in nurseries. Based on the results obtained in the field experiment, the use of mycorrhizal inocula as protection against pathogens is fully advantageous. This method is beneficial for environmental reasons. The use of chemical plant protection products provides temporary protection, only at the time of treatment or for a short period thereafter. Mycorrhized plants are better developed and more resistant to all kinds of stresses, including infections, and the beneficial effect is growing year by year.

\section{CONCLUSIONS}

The presented research results indicate that Alternaria alternata can be pathogenic to juniper, yew, rose and blueberry. The research also confirms the usefulness of mycorrhizal inocula in the protection of the tested plant species against Alternaria alternata. The most important result of the research is the demonstration that mycorrhizal vaccines not only reduced the infection by Alternaria alternata but also had a beneficial effect on the growth and development of studied shrubs.

\section{FUNDING}

This research was financed by the Ministry of Science and Higher Education of the Republic of Poland, DS 3508/KOR.

\section{AUTHOR CONTRIBUTIONS}

M.N. and H.K. - designed and performed experiments, analysed data and wrote the paper; S.M. and J.N. - designed and performed experiments, gave suggestions and corrected the manuscript.

\section{CONFLICT OF INTEREST}

Authors declare no conflict of interest.

\section{REFERENCES}

Abbas M.F., AzIZ-Ud-Din, Rafique K., QAdir A., RASHID A., QAMAR M.I., ET AL., 2017. First report of Alternaria black spot of rose caused by Alternaria alternata in Pakistan. Plant Dis. 101(9), 1676.

Abeer H., Huqail A.A., Allah E.F.A., Alqarawi A.A. 2014. Report and characterization of Alternaria alternata (Fr.) Keissler on Avicennia marina (Forsk.) Vierh forests of industrial Yanb'a city, Saudi Arabia. Pakistan J. Bot. 46(2), 725-734. 
AleKsandrowicz-TrzcińsKa M., 2008. The growth and status of mycorrhization of seedlings in natural regeneration of Scots Pine chemically treated against Lophodermium needle cast. Acta Sci. Pol. Silv. 7(2), 5-16.

ATILANO R.A., 1983. Increase of alternaria blight in two ornamental foliage plant species treated by benomyl. Plant Dis. 67(7), 804-805.

Bagherabadi S., Zafari D., Soleimani M.J., 2015. Genetic diversity of Alternaria alternata isolates causing potato brown leaf spot, using ISSR markers in Iran. J. Plant Pathol. Microbiol. 6(7), 1-6.

Blake J.H., Williamson M., Ellingson C., 2006. Index of Plant Diseases in South Carolina. Clemson University, USA.

Buechel T., Bloodnick E., 2016. Mycorrhizae: Description of types, benefits and uses. Plant Health 4, 18-20.

Chase A.R., 1982. Alternaria leaf spot of Calthlea spp. Plant Dis. 66(10), 953-954.

Chen S., Dai X., Qiang S., Tang Y., 2005. Effect of a nonhost-selective toxin from Alternaria alternata on chloroplast-electron transfer activity in Eupatorium adenophorum. Plant Pathol. 54, 671-677.

Ciuffetti L.M., Manning V.A., Pandelova I., Bettsm M.F., Martinez J.P., 2010. Host- selective toxins, Ptr ToxA and Ptr ToxB, as necrotrophic effectors in the Pyrenophora tritici-repentis-wheat interaction. New Phytol. 187, 911-919.

Domsch K.H., Gams W., Anderson T.H., 2007. Compendium of Soil Fungi. APS Press, USA.

Dugan F., 2006. T he Identification of Fungi: An Illustrated Introduction with Key, Glossary and Guide to Literature. St. Paul, USA.

Ellis M.B., ElLIS J.P., 1988. Microfungi on Miscellaneous Substrates: An Identification Handbook. Croom Helm, Timber Press Portland, Oregon, USA.

FINLAY R.D., 2008. Ecological aspects of mycorrhizal symbiosis: with special emphasis on the functional diversity of interactions involving the extraradical mycelium. J. Exp. Bot. 59(5), 1115-1126.

Ghosh I.P., Mandal D., Laha S., Dasgupta M.K., 2009. Dynamics and severity model in managing fungal diseases. J. Plant Prot. Sci. 1(1), 55-59.

Goetz J., Dugan F.M., 2006. Alternaria malorum: A mini-review with new records for hosts and pathogenicity. Pacific Northwest Fungi 1(3), 1-8.

Grunden E., Chen W., Crane J.L., 2001. Fungi colonizing microsclerotia of Verticillium dahliae in urban environments. Fungal Divers. 8, 129-141.

Guo L.D., Xu L., Zheng W.H., Hyde K.D., 2004. Genetic variation of Alternaria alternata, an endophytic fungus isolated from Pinus tabulaeformis as determined by random amplified microsatellites (RAMS). Fungal Divers. 16, 53-65.

JabŁońSKa L., KowalczyK D., Olewnicki D., 2014. Polish foreign trade in ornamental nursery plants after the accession to the EU. Probl. World Agric. 14 (4), $72-82$.

JAmes R.L., Woo J.Y., 1987. Pathogenicity of Alternaria alternate on young Douglas-fir and Engelman spruce germlings. Technical Report, Forest Pest Management 87-9.

Kakvan N., Zamanizadeh H., Morid B., Taheri H., Hajmansor S., 2012. Study on pathogenic and genetic diversity of Alternaria alternata isolated from citrus hybrids of Iran, based on RAPD-PCR technique. Europ. J. Exp. Biol. 2(3), 570-576.

Klaus H., Domsch W., Gams W., Anderson T., 2008. Compendium of Soil Fungi. St. Paul, USA.

Kredics L.D., Dóczi I., Antol Z., Manczinger L., 2001. Effect of heavy metals on growth and extracellular enzyme activities of mycoparasitic Trichoderma strains. B. Environ. Contam. Tox. 66(2), 249-252.

KURZAWIŃSKA H., 2006. An interaction of potato crop soil fungi population on fungi responsible for tuber superficial diseases. J. Plant Prot. Res. 46(4), 339346.

KurzawińsKa H., Duda-Surman J., 2008. In vitro efficiency of bio-preparations against Stewartia pseudocamellia (Max.) pathogens. Sodininkyste ir Darżininkyste 27(2), 427-435.

Mamgain A., Roychowdhury R., TAH J., 2013. Alternaria pathogenicity and its strategic controls. Res. J. Biol. 1, 1-9.

Marx D.H., Marrs L.F., Cordell Ch.E., 2002. Practical use of the mycorrhizal fungal technology in forestry, reclamation, arboriculture, agriculture, and horticulture. Dendrology 47, 27-40.

Mazur S., Kurzawińska H., Nadziakiewicz M., NAwrocki J., 2015. Redroot pigweed as a host for Alternaria alternata - the causal agent of Alternaria leaf blight in potato. Zemdirbyste-Agriculture 102(1), 115-118.

MirsKi W., 2008. Fungi colonizing shoots of common yew (Taxus baccata L.) in the Jagiellonian University Botanic Garden in Krakow. Acta Agrobot. 61(1), 191-197.

Molina R., 1994. The Role of Mycorrhizal Symbioses in the Health of Giant Redwoods and Other Forest Ecosystems. USDA Forest Service Gen. Tech. Rep. PSW 151, 78-81.

Nasim G., Khan S., Khokhar I., 2012. Molecular polimorfizm and phylogrnrtic relationship of some Alternaria alternata isolates. Pakistan J. Bot. 44(4), 1267-1270.

Pegg K., Duff J., Manners A., 2014. Alternaria diseases in production nurseries. Nursery Production Plant Health \& Biosecurity Project.

Pomerleau R., Nadeau I., 1960. New data on the damping-off of conifer seedlings in Quebec. Report of the Quebec Society for the Protection of Plants from Insects and Fungus Diseases, 27-42. 
Prasad R.D., RANGeShwaran R., 2000. Effect of soil application of a granular formulation of Trichoderma harzianum on Rhizoctonia solani inicited seed rot and damping-off of Phickpea. J. Mycol. Plant Pathol. 30(2), 216-220.

Pusz W., 2009. Morpho-physiological and molecular analyses of Alternaria alternata isolated from seeds of Amaranthus. Phytopathol. 54, 5-14.

Rodino S., Butu M., Petrache P., Butu A., Cornea C.P., 2014. Antifungal activity of four plants against Alternaria alternata. Sci. Bull., ser. F. Biotech. 18, 60-65.

Schirkonyer U., Bauer C., Rothe M., 2013. Ectomycorrhizal diversity at five different tree species in forests of the Taunus Mountains in Central Germany. Open J. Ecology (Berlin) 3(1), 66-81.

Sharma M., Ghosh R., PAnde S., 2013. Occurrence of Alternaria alternata causing Alternaria blight in pigeonpea in India. Adv. Biosci. Biotech. 4, 702-705.
Smith S.E., Read D.J., 2008. Mycorrhizal Symbiosis. Academic Press, London, UK.

Świerczyńska I., Korbas M., HorosZKIEWICZ-JANKA J., Danielewicz J., 2011. Antagonistic effect of Trichoderna viride on pathogenic fungi of grnus Fusarium in presence of biopreparations. J. Res. Applic. Agr. Eng. 56(4), 157-160.

Vayssières A., Pencík A., Felten J., Kohler A., Ljung K., Martin F., et AL., 2015. Development of the Poplar-Laccaria bicolor ectomycorrhiza modifies root auxin metabolism, signaling, and response. Plant Physiol. 169, 890-902.

Woudenberg J.H.C., Truter M., Groenewald J.Z., Crous P.W., 2014. Large-spored Alternaria pathogens in section Porri disentangled. Stud. Mycol. $79,1-47$.

Received October 9, 2017; accepted July 3, 2018 